\title{
Determination of Subjective Well-Being Level in Adolescents in Association with Sport Participation
}

\author{
Ahmet Yavuz Mallı ${ }^{1} \&$ Yasemin Çakmak Yıldızhan ${ }^{1, *}$ \\ ${ }^{1}$ School of Education, Erzincan Binali Yıldırım Üniversitesi, Erzincan, Turkey \\ *Correspondence: School of Education, Erzincan Binali Yıldırım Üniversitesi, Yanlızbağ Yerleşkesi, Erzincan, \\ Turkey. Tel: 90-446-220-0024. E-mail: cakmakyaseminyildizhan@gmail.com
}

Received: November 13, 2018

Accepted: December 5, 2018 Online Published: December 17, 2018

doi:10.5430/wje.v8n6p107

URL: https://doi.org/10.5430/wje.v8n6p107

\begin{abstract}
The aim of this study is to determine the subjective well-being levels of high school students in association with their participation in school sports and to examine whether participating in school sports has an impact on subjective well-being. The research place is the high schools in Erzincan city centre. The sample contains 1004 adolescents including 479 female and 525 male students randomly selected according to the school types. The data of this study are collected by using "Subjective Well-Being Scale" (High School Form) and "Personal Information Form." Research data are analysed using the SPSS 22.0 statistical programme. Mann Whitney U test and Kruskal Wallis $\mathrm{H}$ test are used for the analysis of the data. As a result, it is observed that participation in school sports increases subjective well-being level of students. Subjective well-being level of female students who participate in school sports is higher. School types affect the subjective well-being levels. It is found that the subjective well-being level of the students who do not participate in school sports decreases as the grade of the student increases. The students with the lowest household income have lower subjective well-being levels.
\end{abstract}

Keywords: positive psychology, school sports, sports, subjective well-being

\section{Introduction}

Psychology is the study of human behaviour and the mental process, as well as their underlying causes. Initially, psychology explored the invisible aspects of human behaviour, such as failure, pathology, breakdown, and despair. With the positive psychology movement, it began to focus on the opportunities provided by modern life and show the way to happy life (Caprara \& Cervone, 2003). As a result, the focus of psychology on mental health changed: it was thought that solving the problem of the individual was not enough and that it should contribute to the levels of well-being of humanity. It can be said that positive psychology is a discipline that focuses on the development of positive characteristics and experiences of individuals and the protection of their mental health through programmes that increase their well-being (Seligman \& Csikszentmihalyi, 2000). In literature, subjective well-being takes part under the subject matter of personal development and psychological endurance, and, therefore, it has similar fields of occupation (Sheldon and King, 2001). As mentioned before, subjective well-being, which is one of the topics dwelt on in the field of positive psychology, is expressed as "happiness." Defined as having more pleasant feelings than unpleasant feelings and satisfaction from life (Diener, 1984), subjective well-being is one's subjective belief or feeling that life is going well (Diener \& Lucas, 2000). Subjective well-being is defined to have three components. These are positive affect, negative affect, and life satisfaction. Pleasant feelings include feelings of joy, compassion, pride, while unpleasant feelings include feelings of shame, guilt, sadness, anger, and anxiety (Diener, Suh, \& Oishi, 1997). Life satisfaction is based on evaluative beliefs about one's life. Positive affect and negative affect constitute the affective component of subjective well-being, whereas life satisfaction represents the cognitive component (Myners \& Diener, 1995). Positive affect, negative affect, and life satisfaction schema of the individual determine the level of subjective well-being. Having more pleasant feelings than the negative ones and satisfaction with life are associated with a high subjective well-being level. According to Diener (2000), people experience a high subjective well-being level when they have many pleasant and few unpleasant feelings, when they are engaged in interesting activities, when they experience many pleasures and few pains, and when they are satisfied with their lives (Diener, 2000). 
As in any age group, there are factors that determine the subjective well-being of children and adolescents. The first and the most effective one is genetic susceptibility. Studies show that the determining effect of genetic susceptibility (personal traits such us responsibility, emotional balance, extraversion, openness to experience, and tender mindedness) on subjective well-being was $50 \%$. The second factor is the goal oriented or purposeful behaviours or actions of the individual. These actions, which are thought or aimed by the individuals, affect the subjective well-being by $40 \%$. The third determining factor is demographic characteristics. Demographic characteristics (age, gender, ethnic origin, occupation, and marital status) affect subjective well-being by 10\% (Eryilmaz, 2010).

Studies indicate that sport has also an important part in the daily activities, which affect the subjective well-being by $40 \%$. Sport, made either individually or as a team with pre-set rules, place, time, and area, is an organized human activity which is performed in series and made for a purpose with observable changes (Mathey, 1969). As it is understood from the definition, sport is an activity that is made with a purpose and an intention. The studies show the benefits of physical activity and sport participation on happiness or subjective well-being (Ruseski, 2014). It is a well-known fact that activeness, wellness, and vitality make the individual feel satisfied. The benefits of sport activities include increased self-esteem, self-efficacy, positive self-concept and body image, reduced psychological and physiological stress, and improved feelings of enjoyment and entertainment. These reveal that sport participation increase subjective well-being level as it gives satisfaction and happiness (Yetim, 2001). Therefore, it can be stated that sport participation has also a significant effect on the levels of subjective well-being of adolescents. Adolescence is a period that begins with sexual and psychosocial maturation caused by physical and emotional processes and ends when the individual gains independence, identity, and social productivity. Psychological development in adolescence, which is characterized by biological, psychological and social developments in life; is improved by cognitive and identity developments (Derman, 2008). In a study conducted in our country, the effects of sports activities on behavioural and social development in children and adolescents were investigated. The participants of the study included 26 females and 25 males between the ages 6 and 15. The children and adolescents who participated in the study took the social development inventory of H. J. Eysenck Glenn Wilson at 2-month intervals and it was indicated that participation in sport activities contributed significantly to the social development (Er, Çamlıyer, Çobanoğlu \& Er, 1999). In a study with 89 high school students, Field et al. (2001) found that adolescents who exercise regularly experienced less conflict with their parents, showed less depressive symptoms and substance use, and that their academic standing was above average (Field, Diego \& Sender, 2001). Furthermore, Eryllmaz and Yorulmaz (2006) examined ways to be happy for adolescents. As a result of their study, it was proved that, in order to be happy, adolescents intended to have good relationships with people, to show respect and affection, to seek satisfaction, to have a good academic standing, to be in a romantic relationship, to maintain happiness and to control negative feelings (Eryllmaz \& Yorulmaz, 2006). Tuzgöl-Dost (2006) suggested that the subjective well-being levels of university students were affected by their regular physical activity and, consequently, their positive body image (Tuzgöl Dost, 2006). Another study marked that physical activities performed in free time had positive effect on the subjective and psychological well-being of university students (Cenkseven \& Akbaş, 2007). Şar and Işıklar (2012) investigated the sport self-confidence of athletes in terms of locus of control, subjective well-being, and optimism. The results of the study pointed out that there was a positive and significant association between the levels of the belief of internal locus of control, subjective well-being, optimism and sport confidence, and the levels of the belief of internal locus of control, subjective well-being and optimism predicted the sport confidence significantly (Şar \& Işıklar, 2012). In a study conducted in Spain with 2079 adolescents aged between 14 and 17 years, it was observed that there was a positive relationship between self-efficacy and life satisfaction of the adolescents who were engaged in physical activity (Reigal \& Gil, 2014).

The studies prove that sport activities have a positive effect on the psychological development of individuals. Adolescents' positive expectations towards future may affect their adult life, level of life satisfaction, and mental health. This may, therefore, determine the direction of change and development of society (Şimşek, 2012; Yavuzer, Demir, Meşeci \& Sertelin, 2005). The aim of this study is to determine the subjective well-being levels of high school students participating in school sports and whether participating in school sports has an impact on subjective well-being.

\section{Method}

\subsection{Research Model}

This is a quantitative study in the correlational survey model. The purpose of this study is to determine the predicted level of subjective well-being of high school students in association with their participation in school sports. The 
dependent variable of the study is subjective well-being. The independent variable is the state of participating in the school sports.

\subsection{Research Group}

The study group consists of 1004 high school students, including 479 females and 525 males, who are randomly selected from the secondary schools in the city centre of Erzincan in the 2017-2018 academic year. Of the total 1004 high school students, 389 students, including 131 girls (16.28 \pm 1.06 years) and 267 boys (16.34 \pm 1.04 years), participate in school sports and 606 students, including 348 girls (16.24 \pm 1.12 years) and 258 boys (16.15 \pm 1.06 years), do not participate in school sports.

\subsection{Data Collection Tools}

Data collection tools in this study are personal information form prepared by the researcher and Subjective Well-being Scale (High School Form).

The subjective well-being scale, formed by Tuzgöl-Dost (2004) on university students, was developed for high school students by Özen (2005) and validity and reliability studies were conducted on high school students. The highest possible score of the scale is 185 and the lowest score is 37 . There is a positive correlation between the scores and subjective well-being level (Özen, 2005). Cronbach Alpha reliability coefficient of the scale is found .91 and Pearson product - moment correlation coefficient of the scale is found .82 after test-retest method is performed.

Subjective Well-being Scale is a 37-item, including both positive and negative ones, five-point Likert scale designed to measure judgments of satisfaction with one's life. Scores for each item may range between 1 and 5.15 of these items are negative expressions and 22 of them are positive. Negative expressions are the items $1,3,5,9,12,16,17$, $20,22,25,28,30,31,33$ and 36 . These items are scored inversely.

\subsection{Data Analysis}

In this study, in order to collect personal information, descriptive statistical methods of frequency (n) and percent calculations (\%) are used. Mann Whitney $\mathrm{U}$ test and Kruskal Wallis $\mathrm{H}$ test are used to determine whether samples originate from the same distribution. The significance level was .05 .

\section{Results}

Table 1. Demographic Characteristics of Secondary School Students

\begin{tabular}{|c|c|c|c|c|c|c|c|}
\hline \multirow[t]{2}{*}{ Variable } & \multirow[t]{2}{*}{ Type } & \multicolumn{2}{|c|}{$\begin{array}{l}\text { Participating } \\
\text { in school sports }\end{array}$} & \multicolumn{2}{|c|}{$\begin{array}{l}\text { Not participating in } \\
\text { school sports }\end{array}$} & \multicolumn{2}{|c|}{ Total } \\
\hline & & $\mathrm{f}$ & $\%$ & $\mathrm{f}$ & $\%$ & $f$ & $\%$ \\
\hline \multirow[t]{3}{*}{ Sex } & Female & 131 & 32.9 & 348 & 57.4 & 479 & 47.7 \\
\hline & Male & 267 & 67.1 & 258 & 42.6 & 525 & 52.3 \\
\hline & Total & 398 & 100 & 606 & 100 & 1004 & 100 \\
\hline \multirow[t]{5}{*}{ Grade } & 9th Grade & 120 & 30.2 & 212 & 35.0 & 332 & 33.1 \\
\hline & 10th Grade & 130 & 32.7 & 173 & 28.5 & 303 & 30.2 \\
\hline & 11th Grade & 88 & 22.1 & 144 & 23.8 & 232 & 23.1 \\
\hline & 12th Grade & 60 & 15.1 & 77 & 12.7 & 137 & 13.6 \\
\hline & Total & 398 & 100 & 606 & 100 & 1004 & 100 \\
\hline \multirow[t]{8}{*}{ School Type } & Private High School & 42 & 10.6 & 56 & 9.2 & 98 & 9.8 \\
\hline & Vocational High School & 78 & 19.6 & 170 & 28.1 & 248 & 24.7 \\
\hline & Anatolian High School & 123 & 30.9 & 258 & 42.6 & 381 & 37.9 \\
\hline & Regular High School & 26 & 6.5 & 52 & 8.6 & 78 & 7.8 \\
\hline & İmam Hatip High School & 19 & 4.8 & 39 & 6.4 & 58 & 5.8 \\
\hline & Fine Arts High School & 6 & 1.5 & 31 & 5.1 & 37 & 3.7 \\
\hline & Sports High School & 104 & 26.1 & - & - & 104 & 10.4 \\
\hline & Total & 398 & 100 & 606 & 100 & 1004 & 100 \\
\hline \multirow[t]{6}{*}{ Household Income } & $0-1330 \mathrm{TL}$ & 124 & 31.2 & 172 & 28.4 & 296 & 29.5 \\
\hline & $1301-2600 \mathrm{TL}$ & 135 & 33.9 & 201 & 33.2 & 336 & 33.5 \\
\hline & $2601-3900 \mathrm{TL}$ & 85 & 21.4 & 146 & 24.1 & 231 & 23.0 \\
\hline & $3901-5200 \mathrm{TL}$ & 29 & 7.3 & 56 & 9.2 & 85 & 8.5 \\
\hline & $5200 \mathrm{TL}$ and above & 25 & 6.3 & 31 & 5.1 & 56 & 5.6 \\
\hline & Total & 398 & 100 & 606 & 100 & 1004 & 100 \\
\hline
\end{tabular}


Table 1 indicates that students include 479 (47.7\%) females and 525 (52.3\%) males. 131 (32.9\%) females and 267 $(67,1 \%)$ males participate in sport activities, whereas $348(57.4 \%)$ females and $258(42.6 \%)$ males do not participate in sport activities. There are $332(33.1 \%)$ 9th grade, $303(30,2 \%)$ 10th grade, $232(23,1 \%)$ 11th grade, $137(13,6 \%)$ 12th grade students. $629(62,6 \%)$ of them are vocational high school and Anatolian high school students. 863 (86\%) of the students has a household income between 0-3900 TL.

Table 2. Comparison of Subjective Well-Being of All Secondary School Students According to the Variable of School Sports Participation

\begin{tabular}{lcccccc}
\hline $\begin{array}{l}\text { State of Participating in } \\
\text { School Sports }\end{array}$ & $\mathbf{N}$ & $\begin{array}{c}\text { Average } \\
\text { Rank }\end{array}$ & Total Rank & Med & $\mathbf{Z}$ & $\mathbf{P}$ \\
\hline Participating & 398 & 531.24 & 211435.50 & 141 & -2.546 & $.011^{*}$ \\
Not Participating & 606 & 483.62 & 293074.50 & 139 & \\
\hline
\end{tabular}

Table 2 demonstrates that the subjective well-being level of all the students participating in school sports $(\mathrm{O} . \mathrm{R}=$ $531.24)$ is significantly higher than the students who do not participate in school sports $(\mathrm{O} . \mathrm{R}=483.62)$

Table 3. Comparison of the Subjective Well-Being of Secondary School Female Students According to the Variable of School Sports Participation

\begin{tabular}{lcccccc}
\hline $\begin{array}{l}\text { State of Participating in } \\
\text { School Sports }\end{array}$ & $\mathbf{N}$ & $\begin{array}{c}\text { Average } \\
\text { Rank }\end{array}$ & Total Rank & Med & $\mathbf{Z}$ & $\mathbf{P}$ \\
\hline Participating & 131 & 272.29 & 35670 & 143 & -3.133 & $.002^{*}$ \\
Not Participating & 348 & 227.84 & 79290 & 137 & \\
\hline
\end{tabular}

$* \mathbf{P}<.05$

Table 3 shows that the subjective well-being level of female students participating in school sports $(\mathrm{O} . \mathrm{R}=272.29)$ is significantly higher than the female students who do not participate in school sports $(\mathrm{O} . \mathrm{R}=227.84)$.

Table 4. Comparison of Male Secondary School Students' Subjective Well-Being According to School Sports Participation Variable

\begin{tabular}{lcccccc}
\hline $\begin{array}{l}\text { State of Participating in } \\
\text { School Sports }\end{array}$ & $\mathbf{N}$ & $\begin{array}{c}\text { Average } \\
\text { Rank }\end{array}$ & Total Rank & Med & $\mathbf{Z}$ & P \\
\hline Participating & 267 & 266.47 & 71147.50 & 140 & -.533 & .594 \\
Not Participating & 258 & 259.41 & 66927.50 & 141 & \\
\hline
\end{tabular}

Table 4 projects that there is no significant difference between the subjective well-being levels of the male students who participate in school sports and who do not participate in school sports $(\mathrm{P}>0.05)$.

Table 5. Comparison of Subjective Well-Being Levels of Secondary School Students According to Class Variables

\begin{tabular}{|c|c|c|c|c|c|c|c|c|}
\hline $\begin{array}{l}\text { State } \\
\text { Participating } \\
\text { School Sports }\end{array}$ & $\begin{array}{l}\text { of } \\
\text { in }\end{array}$ & Grade & $\mathbf{N}$ & $\begin{array}{c}\text { Average } \\
\text { Rank }\end{array}$ & Med & $\mathrm{X}^{2}$ & $\mathbf{P}$ & $\begin{array}{c}\text { Different } \\
\text { groups }\end{array}$ \\
\hline \multirow[t]{4}{*}{ Participating } & & $9^{\text {th }}$ Grade & 120 & 208.60 & 142.5 & \multirow{4}{*}{1.929} & \multirow{4}{*}{.587} & \multirow{4}{*}{ - } \\
\hline & & $10^{\text {th }}$ Grade & 130 & 189.05 & 140.5 & & & \\
\hline & & $11^{\text {th }}$ Grade & 88 & 203.35 & 140 & & & \\
\hline & & $12^{\text {th }}$ Grade & 60 & 198.28 & 139 & & & \\
\hline \multirow[t]{4}{*}{ Participating } & & $9^{\text {th }}$ Grade (1) & 212 & 314.37 & 141 & \multirow{4}{*}{7.628} & \multirow{4}{*}{$.054 *$} & \\
\hline & & $10^{\text {th }}$ Grade (2) & 173 & 319.64 & 139 & & & $1-4\left(.025^{*}\right)$ \\
\hline & & $11^{\text {th }}$ Grade (3) & 144 & 290.99 & 136 & & & $2-4(.012 *)$ \\
\hline & & $12^{\text {th }}$ Grade (4) & 77 & 260.69 & 132 & & & \\
\hline
\end{tabular}

$* \mathbf{P}<.05$

Table 5 contains the statistics for grade variable and shows that there is no significant difference between the subjective well-being levels of the students who participate in school sports $(\mathrm{P}>0.05)$. Furthermore, the 9th grade 
$(\mathrm{O} . \mathrm{R}=314.37)$ and 10th grade $(\mathrm{O} . \mathrm{R}=319.64)$ students have a significantly higher subjective well-being than the 12 th grade $(\mathrm{O} . \mathrm{R}=260.69)$ students.

Table 6. Comparison of Secondary School Students' Subjective Well-Being According to School Type Variable

\begin{tabular}{|c|c|c|c|c|c|c|c|}
\hline $\begin{array}{ll}\text { State of } \\
\text { Participating in } \\
\text { School Sports }\end{array}$ & School Type & $\mathbf{N}$ & $\begin{array}{c}\text { Average } \\
\text { Rank }\end{array}$ & Med & $\mathbf{X}^{2}$ & $\mathbf{P}$ & $\begin{array}{c}\text { Different } \\
\text { groups }\end{array}$ \\
\hline \multirow{7}{*}{ Participating } & Private High School (1) & 42 & 187.64 & 138.5 & \multirow{7}{*}{18.060} & \multirow{7}{*}{$.006^{*}$} & \multirow{7}{*}{$\begin{array}{l}2-3 * \\
3-4 * \\
3-7 *\end{array}$} \\
\hline & Vocational High School (2) & 78 & 185.72 & 137 & & & \\
\hline & Anatolian High School (3) & 123 & 224.98 & 146 & & & \\
\hline & Regular High School (4) & 26 & 173.23 & 133.5 & & & \\
\hline & İmam Hatip High School (5) & 19 & 251.00 & 153 & & & \\
\hline & Fine Arts High School (6) & 6 & 104.58 & 120 & & & \\
\hline & Sports High School (7) & 104 & 139 & 187.12 & & & \\
\hline \multirow{7}{*}{$\begin{array}{l}\text { Not } \\
\text { Participating }\end{array}$} & Private High School (1) & 56 & 364.96 & 145.5 & \multirow{7}{*}{16.330} & \multirow{7}{*}{$.006^{*}$} & \multirow{7}{*}{$\begin{array}{l}1-2^{*} \\
1-4^{*} \\
1-5^{*} \\
1-6^{*} \\
2-3^{*} \\
3-5^{*}\end{array}$} \\
\hline & Vocational High School (2) & 170 & 276.36 & 134 & & & \\
\hline & Anatolian High School (3) & 258 & 319.83 & 140.5 & & & \\
\hline & Regular High School (4) & 52 & 288.75 & 136 & & & \\
\hline & İmam Hatip High School (5) & 39 & 260.51 & 132 & & & \\
\hline & Fine Arts High School (6) & 31 & 284.26 & 140 & & & \\
\hline & Sports High School (7) - & & - & - & & & \\
\hline
\end{tabular}

$* \mathbf{P}<.05$

Table 6 illustrates that the subjective well-being level of the Anatolian high school students $(\mathrm{O} . \mathrm{R}=224.98)$ who participate in sport activities is significantly higher than the students of vocational high school (O.R=185.72), regular high school $(\mathrm{O} . \mathrm{R}=173.23)$, and sports high school $(\mathrm{O} . \mathrm{R}=187.12)$. The subjective well-being level of private high school students $(0 . \mathrm{R}=364.96)$ who do not participate in sport activities is significantly higher than the students of vocational high school $(\mathrm{OR}=276.36)$, high school $(\mathrm{OR}=288.75)$, imam hatip high school $(\mathrm{OR}=260.51)$, and fine arts high school $(\mathrm{OR}=284.26)$. The subjective well-being level of Anatolian high school students $(\mathrm{OR}=319.83)$ who participate in sport activities is significantly higher than the students of vocational high school $(\mathrm{OR}=276.36)$ and imam hatip high school $(\mathrm{OR}=260.51)$.

* There is not any statistical analysis for imam hatip and fine arts high schools due to the lack of students studying in and participating in the school sports, and for sports high school due to the lack of sports high school students who do not participate in school sports.

Table 7. Comparison of Subjective Well-Being of Secondary School Students According to Household Income Level Variable

\begin{tabular}{|c|c|c|c|c|c|c|c|}
\hline $\begin{array}{ll}\text { State } & \text { of } \\
\text { Participating } & \text { in } \\
\text { School Sports } & \\
\end{array}$ & Household Income & $\mathbf{N}$ & $\begin{array}{c}\text { Average } \\
\text { Rank }\end{array}$ & Med & $\mathbf{X}^{2}$ & $\mathbf{P}$ & $\begin{array}{c}\text { Different } \\
\text { groups }\end{array}$ \\
\hline \multirow[t]{5}{*}{ Participating } & $0-1330$ TL (1) & 124 & 186.14 & 137 & \multirow{5}{*}{4.514} & \multirow{5}{*}{.341} & \multirow{5}{*}{$8-1$} \\
\hline & $1301-2600 \mathrm{TL}(2)$ & 135 & 204.06 & 141 & & & \\
\hline & 2601-3900 TL (3) & 85 & 218.08 & 146 & & & \\
\hline & $3901-5200$ TL (4) & 29 & 188.40 & 135 & & & \\
\hline & Above 5200 TL (5) & 25 & 190.88 & 136 & & & \\
\hline \multirow[t]{5}{*}{ Not Participating } & $0-1330$ TL (1) & 172 & 268.86 & 134 & \multirow{5}{*}{14.865} & \multirow{5}{*}{$.005 *$} & \multirow{5}{*}{$\begin{array}{l}1-2\left(.041^{*}\right) \\
1-3\left(.023^{*}\right) \\
1-4\left(.000^{*}\right) \\
2-4\left(.018^{*}\right)\end{array}$} \\
\hline & $1301-2600$ TL (2) & 201 & 305.68 & 139 & & & \\
\hline & 2601-3900 TL (3) & 146 & 314.04 & 140 & & & \\
\hline & $3901-5200$ TL (4) & 56 & 367.07 & 144 & & & \\
\hline & Above 5200 TL (5) & 31 & 317.03 & 137 & & & \\
\hline
\end{tabular}

$* \mathbf{P}<.05$ 
Regarding income level, Table 7 demonstrates that there is no significant difference between the groups in terms of subjective well-being of the students participating in school sports $(\mathrm{P}>0.05)$.

There is a positive correlation between the income and subjective well-being levels of the students who do not participate in school sports. The level of subjective well-being of the students with the lowest income level (0-1330 $\mathrm{TL})$ is found to be the lowest $(\mathrm{O} . \mathrm{R}=268.86)$. Higher income is associated with higher subjective well-being level. As a result of the analysis, the subjective well-being levels of the students with the income level of 0-1330 TL is lower than the students with income levels of 1301-2600 TL, 2601-3900 TL, and 3901-5200 TL.

\section{Discussion}

This study investigates the effects of school sports participation on the subjective well-being of the students. The results indicate that students who participate in sport have higher levels of subjective well-being (Table 2). Regarding gender effects in this context, it is found that female students who participate in sport have higher subjective well-being levels than the female students who are not physically active. However, there is no significant difference between the levels of subjective well-being of male students who participate in sport and who do not (Table 4). The large scale studies made in various countries by using different methods and measures on Kenneth R Fox's study have revealed the positive correlation between physical activity and subjective well-being (Fox, 1999). The empirical studies show that moderate psychical activity will have a positive effect on the mood, and if the participants focus on their personal development goals, an increase in their subjective well-being is also expected. Based on the data obtained from the 2009 population survey in Rheinberg, Germany, Jane Ruseski (2012) finds that the life happiness of the individuals who participate in sport are higher (Ruseski, Humphreys, Hallman, Wicker \& Breuer, 2014). Likewise, Downward and Rasciute's study examining the relationship between sport participation and happiness suggests that sport participation has a positive effect on subjective well-being (Downward \& Rasciute, 2011). Sezer's (2011) study with 410 high school students, Çağlayan Tunç's (2015) study with university students and Kaplan's (2016) study with high school students add to the evidence of this positive correlation (Sezer, 2011; Çağlayan Tunç, 2015; Kaplan, 2016). Moreover, studies conducted by Özcan (2017), Polat (2017), Doğaner (2017) and Yaran (2014) mark that there is a positive relationship between sport participation and life satisfaction, quality of life, and happiness (Özcan, 2017; Polat, 2017; Doğaner, 2017; Yaran, 2014).

The results show that there is no difference between the subjective well-being levels of the students participating in school sports in terms of their grades. However, the students who do not participate in school sports in the 9th and 10th grade have significantly higher subjective well-being levels than the 12th grade students (Table 5). Saygin's (2008) study on university students finds that the subjective well-being levels of the 1st and 2nd grade are significantly higher than the 3rd grade students (Saygın, 2008). Similarly, Dilmaç and Bozgeyikli's (2009) study on 600 teacher candidates indicates that the subjective well-being levels of the teacher candidates in their third year at the university are significantly higher than the ones who are in the fourth year (Dilmaç ve Bozgeyikli, 2009). İlhan's (2005) study on 454 university students, however, shows that study years have a low effect on the subjective well-being levels (İlhan, 2005).

School types have an effect on students' participating in the sports and cause significant differences among the groups. The results reveal that the subjective well-being levels of Anatolian high school students are higher than vocational high school, regular high school and sports high school students (Table 6). Sezer's study (2011) on secondary school students and Çelik's (2008) study on 485 high school students suggest a significant difference between school types and subjective well-being levels (Sezer, 2011; Çelik, 2008). In addition, Elmas's (2013) study on the life satisfaction level of 504 high school students proves that Anatolian high school and imam hatip high school students' life satisfaction scores are more positive than students in trade vocational high schools (Elmas, 2013).

There is not any significant difference among the groups when subjective well-being levels of the students participating in school sports are examined by the household income. However, subjective well-being levels of the students who do not participate in school sports have a positive correlation (Table 7). The studies of Tuzgöl Dost (2004), Özen (2005) and Canbay (2010) also add to the evidence of this significant correlation (Tuzgöl Dost, 2004; Özen, 2005; Canbay, 2010). Kara's (2014) study with high school students indicates a positive relationship between psychological well-being and income levels and, similarly, Işık and Koçak's (2014) study with university students suggests a positive association between income level and life satisfaction (Kara, 2014; Işık \& Koçak, 2014). Bozkurt and Sönmez's (2016) study finds that students who think that the pocket money given to them is enough have higher subjective well-being levels than the students who do not find the amount adequate (Bozkurt \& Sönmez, 2016). 
Likewise, Gündoğar et al. (2007) and Chow's (2005) studies with university students show that higher socio-economic level leads to higher life satisfaction level (Gündoğar, Gül, Uskun, Demirci \& Keçeci, D. 2007; Chow, 2005).

In conclusion, participation in sports competitions in the school increases subjective well-being levels of the students, school types have an impact on the subjective well-being levels, there is a negative correlation between the subjective well-being levels of the students who do not participate in sports competitions and their grades, and school sports participation eliminates the economic differences affecting the subjective well-being levels. In this respect, it can be deduced that participation in sports competitions in the school has a positive effect on the psychological development of the students and provides social, cultural, and physical benefits. It is suggested that students should be informed and directed more on this subject. New research that determine the psychological benefits of doing sports in young people is recommended.

\section{References}

Bozkurt, E., \& Sönmez, H. İ. (2016). Investigation according to personal and social features of adolescent subjective well-being of imam preachers middle school students. Review of the Faculty of Divinity of Amasya University, 7 , 231-248.

Caprara, G. V., \& Cervone, D. (2003). A conception of personality for a psychology of human strengths: personality as an agentic, self regulating system. In: L. G. Aspinwall \& U. M. Staudinger, (Eds.), A Psychology of Human Strenghts: Fundamental Questions and Future Directions for a Positive Psychology. Washington: DC American Psychological Association, pp. 61-74. https://doi.org/10.1037/10566-005

Canbay, H. (2010). The assessment of the relationship between the levels of subjevtive well-being and the levels of social skills of the high scholl students. Master Thesis. Dokuz Eylül University, İzmir. UMI: 278478.

Cenkseven, F., \& Akbaş, T. (2007). Examining the predictors of subjective and psychological well-being of university students. Turkish Psychological Counseling and Guidance Journal, 3(27), 43-65.

Chow, H.P.H. (2005). Life Satisfaction among university students in a Canadian prairie city: a multivariate analysis. Social Indicators Research, 70, 139-150. https://doi.org/10.1007/s11205-004-7526-0

Çağlayan Tunç, A. (2015). Effects of sports on social anxiety and sobjective well - being levels of university students. Master Thesis. Selçuk University, Konya. UMI:409341.

Çelik, Ş. (2008). The investigation of the subjective well-being of the high school students in terms of emotional intelligence. Master Thesis. Selçuk University, Konya. UMI:409341.

Derman O. (2008). Psychosocial development in adolescence. Istanbul University Cerrahpaşa Medical Faculty Continuing Medical Education Activities Adolescence Health II Symposium, 63, 19-21.

Diener, E. (1984). Subjective well-being. Psychological Bulletin, 95(3), 542-575. https://doi.org/10.1037/0033-2909.95.3.542

Diener, E. (2000). Subjective well-being: The science of happiness and a proposal for a national index. American Psychologist, 55(1), 34-43. https://doi.org/10.1037/0003-066X.55.1.34

Diener, E., \& Lucas, R. E. (2000). Personality and subjective well-being across the life span. Temperament and Personality Development Across the Life Span, 221-244.

Diener, E., Suh, E., \& Oishi, S. (1997). Recent findings on subjective well-being. Indian Journal of Clinical Psychology, 24, 25-41.

Dilmaç, B., \& Bozgeyikli, H. (2012). A research on subjective well-being and decision making of teacher candidates. Erzincan University Journal of Education Faculty, 11(1), 171-187.

Doğaner, S. (2017). The effect of regular exercise program on individuals' stress, happiness, and leisure satisfaction levels. PhD Thesis, Ankara University, UMI: 462822.

Downward, P., \& Rasciute, S. (2011). Does sport make you happy? An analysis of the well-being derived from sports participation. International Review of Applied Economics, 25(3), 331-348. https://doi.org/10.1080/02692171.2010.511168

Elmas, İ. H. (2013). Life satisfaction level of highschool students. Master Thesis, Hasan Kalyoncu University, Gaziantep. UMI: 454241. 
Er, G., Çamlıyer, H., Çobanoğlu, G., \& Er, N. (1999). The effects of sport activities on children and adolecence in the means of manner and social development. CBÜ Journal of Physical Education and Sport Sciences, 3, 29-38.

Eryllmaz A. (2010). Developing a scale about subjective well being increases strategies for adolescents. Turkish Psychological Counseling and Guidance Journal, 4(33), 81-88.

Eryllmaz, A., \& Yorulmaz, A. (2006). The Way of being happy for adolescents. Paper presented at the Xth Conference of European Association for Research on Adolescence, Antalya, Turkey, pp. 2-6.

Field, T., Diego, M., \& Sender, C.E. (2001). Exercise is positively related to adolescents' relationships and academics. Adolescence, 36, 105-110.

Fox, K.R. (1999). The influence of physical activity on mental well-being. Public Health Nutr, 2(3a), 411-418. https://doi.org/10.1017/S1368980099000567

Gündoğar, D., Gül, S. S., Uskun, E., Demirci, S., \& Keçeci, D. (2007). Investigation of the predictors of life satisfaction in university students. Clinical Psychiatry, 10(1), 14-27.

Işık, Ö. G., \& Koçak, Ö. F. (2014). An investigation on life satisfaction of students in faculty of communication by different variables. Journal of Selçuk Communication, 8(3), 281-300.

İlhan, T. (2005). A model of humor styles based on subjective well-being. Master Thesis, Gazi University, Ankara. UMI:159598.

Kaplan, K. (2016). Leisure time exercise participation, self well-being, self-sufficiency: A thesis on high school students. Master Thesis, Akdeniz University, Antalya. UMI:440652

Kara, S. (2014). Examining the relationship between school burnout and psychological well-being levels of high school students in terms of different variables. Master Thesis, Sakarya University, Sakarya. UMI: 385884

Mathey, E. (1969). This thing colled sport. Y Health Physical, 40(2), 38.

Myers, D., \& Deiner, E. (1995). Who is happy. American Psychological Society, 6(1), 1-19. https://doi.org/10.1111/j.1467-9280.1995.tb00298.x

Özcan, B. (2017). Levels of life satisfaction and self efficacy of obese women who do exercises and those who don't. Master Thesis, Mersin University, Mersin. UMI:473554.

Özen, Ö. (2005). Subjective well-being of adolescents. Master Thesis, Hacettepe University, Ankara. UMI:159960.

Polat, A. (2017). And do not exercise of the members of the safety of life satisfaction job satisfaction and burnout levels. (Sakarya province). Master Thesis, Sakarya University, Sakarya. UMI: 358193

Reigal, R., Videra, A., \& Gil, J. (2014). Physical exercise, general self-efficacy and life satısfaction in adolescence. Revista Internacional de Medicina y Ciencias de la Actividad Física y del Deporte, 14(55), 561-576.

Ruseski, J. E., Humphreys, B. R., Hallman, K., Wicker, P., \& Breuer, C. (2014). Sport participation and subjective well-being: Instrumental variable results from German survey data. Journal of Physical Activity and Health, 11, 396-403. https://doi.org/10.1123/jpah.2012-0001

Saygin, Y. (2008). Investigating socil support, self-esteem and subjectiwe well-being levels of university students, Master Thesis, Selçuk University, Konya. UMI:218666

Seligman, M. E. P., \& Csikszentmihalyi, M. (2000). Positive psychology: An introduction. American Psychologist, 55(1), 5-14. https://doi.org/10.1037/0003-066X.55.1.5

Sheldon, K. M., \& King, L. (2001). Why positive psychology is necessary. American Psychologist, 56(3), 216. https://doi.org/10.1037/0003-066X.56.3.216

Şar, A. H., \& Işıklar, A. (2012). Examination of locus of control, subjective well-being and optimism as the predictors of sport confidence. Nigde University Journal of Physical Education and Sport Sciences, 6(1), 76-84.

Sezer, F. (2011). The analysis of subjective well-being of secondry school students' in terms of some variables. Journal of Turkey National Education, 41(192), 74-85.

Şimşek, H. (2012). Future expectations of high school students in southeastern turkey: factors behind future expectations. Journal of Theoretical Educational Science, 5(1), 90-109.

Tuzgöl Dost, M. (2006). Subjective well-being among university students. Hacettepe University Journal of Education, 31, 188-197. 
Tuzgöl Dost, M. (2007). Examining life satisfaction levels of university students in terms of some variables. pamukkale University Journal of Education, 22(2), 132-143.

Yaran, M. (2014). Investigation of sleep quality and quality of life in University students who make sports and who do not. Master Thesis. Ondokuz Mayıs University, Samsun. UMI: 352785

Yavuzer, H., Demir, İ., Meşeci, F., \& Sertelin, Ç. (2005). Future expectations of today's youth. HAYEF: Journal of Education, 2, 93-103.

Yetim, Ü. (2001). Happiness from Society. İstanbul: Bağlam Press. 